\title{
IN-SERVICE PRIMARY SCIENCE TEACHERS' DEVELOPMENT AND IMPLEMENTATION OF GAME-BASED LEARNING FOR NUTRITION TOPIC THROUGH AN INTENSIVE TRAINING WORKSHOP
}

\author{
Ong Dee Jean 1 \\ ${ }^{1}$ College of Hospitality Industry Management, Suan Sunandha Rajabhat University, \\ Nakhon Pathom 73170 Thailand \\ * Corresponding author: dee.on@ssru.ac.th
}

\begin{abstract}
:
This research examines how an intensive training workshop contributes to in-service primary science teachers' development and implementation of game-based learning in nutrition topic for Grade 6 students. A multi-case study was applied. Three in-service primary science teachers from two primary schools in Samut Sakorn and one from Nakhon Pathom Province, Thailand participated in the intensive training workshop. Data collection included workshop and classroom observation, individual interview, group meeting, CoRe worksheet, 2-days intensive training workshop and classroom implementation video-recorded with camcorders to capture teachers' development and implementation of game-based learning in nutrition topic for Grade 6 students. The constant comparative method for within-case analysis and cross-case analysis was used. The results showed that in-service primary science teachers increased understanding about game-based learning and, to some extent, showed their ability to implement game-based learning in teaching about nutrition topic for Grade 6 students. The created intensive training helps the participating in-service primary science teachers develop their understanding and ability to teach the nutrition topic with game-based learning.
\end{abstract}

Key words: - In-service primary science teachers, Game-based learning, Nutrition topic.

\section{INTRODUCTION:}

The epidemic of childhood obesity in Thailand has led schools and policymakers focus on nutrition education (Chavasit et al., 2013). Nutrition education that incorporates experiential cooking (Jarpe-Ratner et al., 2016), pedagogic meals (Osowski et al., 2013), school-based kitchen garden program (Gibbs et al., 2013), healthy eating, dietary intake in schools have effectively increased student's nutrition knowledge (Asakura et al., 2017). Despite numerous programs that promote nutrition education, enhancing students' knowledge of healthy eating was not sustainable enough for long-life healthy eating (Benton, 2004). Training teachers (Durlak and Dupre, 2008) to use game-based learning activities can increase students' knowledge about nutrition ("Guidelines for School Health Programs to Promote Healthy Eating" [Centers for Disease Control and Prevention (CDCP,2011)]. Game-based learning is becoming increasingly popular and widely adopted for students' learning (Pivec et al., 2014). Studies on the impact of game-based learning yielded mixed results. Yien (2011) found that sixth grade students in the experimental group showed greater learning interest, better attitude and learning achievement towards the use of game-based learning in food eating habits. Munoz et al. (2017) reported that third-, fourth-, and fifthgraders in the treatment group felt that reading with augmented reality game-based learning was more pleasurable and enjoyable. A study of primary school-going students 
reported that game-based learning increased their learning motivation. They enjoyed playing the board game about space and solar system (Kirikaya et al., 2010). Chen et al. (2012)'s study mentioned that fourth grade students wanted to play the card game about transportation and energy repeatedly. However, how significant was the increase in the students' motivation and learning interest remained unclear (Druckman, 1995). Nevertheless, game-based learning can also provide opportunities for sociocultural and collaborative learning for the students (Druckman, 1995; Munoz et al., 2017) as well as students' cognitive, motivational, affective and sociocultural aspects (Plass et al., 2015). To date, the majority of research on gamebased learning has focused on student impact in science, language and mathematics. Little research has been conducted in game-based learning in nutrition topic. Furthermore, little is known about teachers' knowledge in gamebased learning (Shah and Foster, 2015) in nutrition topic. Up to now, just one study of 14 pre-service teachers' acquired knowledge and implementation of Game Network Analysis (GaNA) has provided a most insightful, detailed outline of teachers' knowledge of game-based learning (Shat and Foster, 2015). Teachers may have the most influence in the students, training teachers with good knowledge of game-based learning in nutrition may help to combat childhood obesity. The main objective of this study was to examine how training contributes and impacts in-service science teachers' development and implementation of game-based learning in nutrition topic in grade six.

\section{MATERIAL \& METHODS:}

Participants: This study included 2 primary schools in Samut Sakorn and 1 primary school in Nakhon Pathom, Thailand. 3 in-service science teachers from each school participated voluntarily in the intensive training workshop. Inclusive criteria included participating teachers teaching nutrition topic in grade 6 and they must be English speaking. Gender, race, educational background and socioeconomic status were excluded. Formal letter of invitation was hand-delivered to the principal before the training workshop and classroom observation began as part of the regulations required by the educational institution in Thailand.

In total, 5 classroom observations were conducted. A total of 112 students participated in the game-based learning in the classroom observation. Of which, 47 students were from the first school (23 and 24 students from each class). There were 31 students in the second school (15 and 16 students in each class) and 29 students from 1 class in the third school. Participant consent form was collected before training workshop. Parental consent form was collected before classroom observations.

Study Design: A four-month multi-case study was conducted. Prior to the training, phone interviews were conducted to gage participating teachers' experiences about game-based learning. Participating teachers attended a 2-day 8 hours intensive training workshop on game-based learning. After which, classroom implementation observation data were collected during 3 different days in each school. In the first school, 2 classes, 120 minutes in each class was observed. In the second school, 2 classes were observed, 100 minutes each. Only 1 class with 100 minutes was observed in the third school. The classroom implementation observation data was open-ended observation, with follow-up interviews immediately when each class finished. All interviews, training workshop 
sessions and classroom observations were video-recorded with camcorders to capture teachers' development and implementation of game-based learning in the nutrition topic.

Instruments, Measures and Procedures: Content Representation (CoRe). The participating teachers were first asked to share their pre-existing knowledge about CoRe. After that, they learnt about the objectives and elements in CoRe. They had 90 minutes to write their individual pre-CoRe and present thereafter. The researcher shared a sample CoRe with the teachers. They used 120 minutes to rewrite and present their postCoRe. After that, they discussed the strengths and weaknesses of CoRe. Both pre- and postCoRe's were collected for data analysis.

Game-based learning. The participating teachers first learnt the basics of game-based learning through presentation slides and video clips. After that, they played the Mission N card game and Calorie Counter! Board game. Mission $\mathrm{N}$ card game is a fun educational card game created for primary school students to learn about five food groups and simple food vocabulary. Calorie Counter! Board game is a collaborative, educational board game designed for primary school students to learn about nutrients and caloric intake. The researcher explained the rules of Mission $\mathrm{N}$ card game and played simultaneously for 120 minutes with 7 different variations. After that, the researcher took 15 minutes to explain the Calorie Counter! board game rules. The teachers played the board game 2 rounds, lasting 60 minutes each round. They made notes as they played to familiarize with the board game rules.

Classroom implementation. After the intensive training, the participating teachers conducted games in the classroom in their respective schools on an appointed date. Before that, all the teachers pre-trained their students to play the card games and board game. Teacher A did not pre-train the students to do the board game because of time constraint. Participating teachers were free to execute the games in any sequence, manner, student grouping or seating arrangement. The researcher made notes of the teachers' instructions, students' interaction with the games and their peers. A pre- and post- nutrition quiz was administered. Interviews were conducted immediately and video-recorded after each classroom implementation.

Data Analysis: The constant comparative method for within-case and cross-case analysis were used. Interview data were first transcribed verbatim. Then, the researcher sifted through the data and arranged the information from interview transcripts, classroom observation, CoRe and artefacts using data reduction (Kolb, 2012). Next, the researcher open-coded the data (Strauss and Corbin, 2008) by constantly comparing them and asking questions about what was comprehensible and what not. Axial coding was used to induce and deduce the associated subcategorizes by consistently making comparison (Strauss and Corbin, 2008). Finally, selective coding was used to link the categories for further refining and development. Throughout, the researcher used Magnusson's components of science teaching (Magnusson et al.,1999) for data analysis which comprises: 1) orientation to science teaching, 2) knowledge about goals and objectives, 3) knowledge about students' understanding, 4) knowledge about instructional strategies and 5) knowledge about ways of assessing the specific topic.

RESULTS AND DISCUSSION: 
Within case analysis and results of the crosscase analysis of in-service primary science teachers' development and implementation in game-based learning are shown in the tables below.

Table : 1 After the intensive training workshop, Teacher A showed some improvement in adopting game-based learning in the classroom. She was keen to learn more games and use them to teach nutrition topic.

Table : 2 After attending the intensive training workshop, Teacher B became confident in using games in the classroom. He fell in love with CoRe and wanted to share this with the teachers in his school. He was extremely excited to teach his students how to make their own card games.

Table 3 Teacher $\mathrm{C}$ became more confident in using games in the classroom after attending the intensive training workshop. She wanted to replace her lesson plans with CoRe. She was confident enough to allow the students to modify the game rules.

Table 4 Of the 20 indicators assessed, Teacher A had little ability to use the boardgame in class (no. 4, 8, 13, 15) compared to Teachers B and $\mathrm{C}$. Teachers $\mathrm{B}$ and $\mathrm{C}$ had better mastery in the board game (no. 5, 7, 17 and 18) and as a result, students enjoyed the board game more and learn about nutrition concepts (no. 10). Teacher $B$ and $C$ were equally good in assessing students' understanding of nutrition knowledge (no. 19) as they made learning relevant to the students (no. 1, 9 and 11). Overall, all teachers used the card games well (no. 2, 3, 12, 14 and 16).

Findings of this study provided insight into the impact of training for game-based learning in nutrition topic for in-service science teachers. The participating teachers reported that the training in CoRe had helped them to develop and articulate their nutrition knowledge in a boarder, comprehensive manner, compared to lesson-plan writing. With studies (Bertram, 2015; Loughran et al., 2004; Williams, 2012) demonstrating that the use of CoRe design has the potential for development of novice teachers, training in equipping teachers in CoRe construction is absolutely needed. In one 2-year longitudinal study of a beginning science teacher, he found that CoRe had scaffold his knowledge of teaching and learning about science in new ways beyond his ordinary teaching thinking (Bertram, 2015). In another study, the course lecturer saw the potential for enhancing 9 pre-service teachers' knowledge in chemistry education by encouraging them to construct their own CoRe for new topics (Hume and Berry, 2010).

Another interesting finding from this study was related to teachers' experience in using the card game and board game in the classroom implementation. These results are consistent with previous studies of positive outcomes in game-based learning (Chen et al., 2012; Delacruz, 2012; Druckman, 1995; Ernest, 1986; Jabber and Felicia, 2015; Kirikaya, 2010; Mostowfi et al., 2016, Munoz et al., 2017; Pivec et al., 2014; Plass et al., 2015; Viraj, 2016; Yien, 2011). The participating teachers reported that the students enjoyed the Mission N card game because it was fun and easy to play. In contrast, the Calorie Counter! board game rules were too complicated and required modifications. Game rules should therefore be simple, competitive yet engaging (Baranauskas et al., 1999; Garris et al., 2002, Johnston and de Felix, 1993; Malone, 1981, Pivec et al., 2014, Shaffer et al., 2005; Thornton and Cleveland, 1990).

\section{CONCLUSIONS}

The results suggest that the intensive training helps the participating in-service primary science teachers develop their understanding 
and ability to teach the nutrition topic with game-based learning. Recognizing that teachers play a vital role in influencing the students in their nutrition knowledge, policies may include budget for training teachers for game-based learning in nutrition topic. Gamebased learning is engaging and appealing to students. School administrators could consider implementing game-based learning into their nutrition topic in the curriculum. The successful implementation of game-based learning requires school nutrition efforts (Chapman-Novakofski, 2012). Without such changes, childhood obesity in Thailand may remain a serious problem.

\section{REFERENCES:}

Amin SA, Yon BA, Taylor JC and Johnson RK, 2015. Impact of the National School Lunch Program on fruit and vegetable selection in north eastern elementary schoolchildren, 2012-2013. Public Health Rep, 130:453-457.

Asakura K, Todoriki H and Sasaki S, 2017. Relationship between nutrition knowledge and dietary intake among primary school children in Japan: Combined effect of children's and their guardians' knowledge. Journal of Epidemiology, 27(10): 483-491.

Baranauskas CC, Neto GG and Borges, MAF, 2001. Learning at work through a multiuser synchronous simulation game. International Journal of Continuing Engineering Education and Life-Long Learning, 11(3):137-144.

Benton D, 2004. Role of parents in the determination of the food preferences of children and the development of obesity. International Journal of Obesity Related Metabolism Disorder, 28(7): 858-869.

Centers for Disease Control and Prevention. (CDCP) 2011. Guideline 5. Implement health education that provides students with the knowledge, attitudes, skills, and experiences needed for heathy eating and physical activity. Morbidity and Mortality Weekly Report: School health guidelines to promote healthy eating and physical activity, 60(5): 3337. Retrieved from https://www.cdc.gov/healthyschools/n pao/pdf/MMWR-School-Health-

Guidelines.pdf

Chapman-Novakofski, K, 2012. Best practices for school nutrition efforts. Journal of Nutrition Education and Behavior, 44(5):389.

Chavasit V, Kasemsup V and Tontisirin, K, 2013. Thailand conquered undernutrition very successfully but has not slowed obesity. Obesity Reviews, 14(2): 96-105.

Chen PG, Liu EZF, Lin CH, Chang WL and Tien $\mathrm{HH}, 2012$. Developing an educational card game for science learning in primary education. 2012 Fourth International Conference on Digital Game and Intelligent Toy Enhanced Learning. 236-240.

Delacruz GC, 2011. Games as formative assessment environments: Examining the impact of explanations of scoring and incentives on math learning, game performance, and help seeking. CRESST REPORT 796. The National Center for Research on Evaluation, Standards, and Student Testing.

Druckman D, 1995. The educational effectiveness of interactive games. In D. Crookall, \& K. Arai (Eds.), Simulation and Gaming Across Disciplines and Cultures: ISAGA At A Watershed (pp.178-187). New York: SAGE Publications. 
Durlak JA and Dupre EP, 2008. Implementation matters: A review of research on the influence of implementation on program outcomes and the factors affecting implementation. American Journal of Community Psychology, 41: 327-350.

Ernest P, 1986. Games: A rationale for their use in teaching mathematics in school, Mathematics in School, 2: 1-8.

Garris R, Ahlers R and Driskell JE, 2002. Games, motivation and learning: A research and practice model. Simulation and Gaming, 33(4): 441-467.

Gibbs L, Staiger PK, Johnson B, Block K, Macfarlane S, Gold L, Kulas J, Townsend $\mathrm{M}$, Long $\mathrm{C}$ and Ukoumunne O, 2013. Expanding children's food experiences: the impact of a schoolbased kitchen garden program. Journal of Nutrition Education and Behavior, 45(2):137-146.

Gross SM, Biehl E, Marshal B, Paige DM and Mmari K, 2018. Role of the elementary school cafeteria environment in fruit, vegetable, and whole-grain consumption by 6- to 8-year-old students. Journal of Nutrition Education and Behavior, 51(1):41-47.

Jabbar A and Felicia P, 2015. Gameplay engagement and learning in game-based learning: a systematic review, Review of Educational Research, 85(4): 740-779.

Jarpe-Ratner E, Fokens S, Sharma S, Daro D and Edens NK, 2016. An experiential cooking and nutrition education program increases cooking self-efficacy and vegetable consumption in children in Grades 3-8. Journal of Nutrition Education and Behavior, 48(10):697705.e1.
Johnston RT and de Felix W, 1993. Learning from video games. Computer in The Schools, 9: 199-233.

Kirikkaya EB, Iseri S and Vurkaya G, 2010. A board game about space and solar system for primary school students. The Turkish Online Journal of Educational Technology, 45(4): 499-519.

Kolb SM, 2012. Grounded theory and the constant comparative method of qualitative analysis. Social Problems, 12(4): 463-445.

Loughran J, Mulhall P and Berry A, 2004. In search of pedagogical content knowledge in science: Developing ways of articulating and documenting professional practice. Journal of Research in Science Teaching, 41(4): 370-391.

Magnusson S, Krajcik J and Borko, H, 1999. Nature, sources, and development of pedagogical content knowledge for science teaching. In J. Gess-Newsome \& N. G. Lederman (Eds.), Examining Pedagogical Content Knowledge: The Construct and Its Implication for Science Education (pp. 95-132), Dordrecht, the Netherlands: Kluwer Academic.

Malone TW, 1981. What makes computer games fun? Byte, 6(12): 258-277.

Mostowfi S, Mamaghani NK and Khorramar, M, 2016. Designing playful learning by using educational board game for children in the range of 7-12: (A case study: Recycling and waste educational board game). International Journal of Environmental and Science Education, 11(12): 5453-5476.

Munoz HT, Baldiris S and Fabregat R, 2017. Augmented reality game-based learning: Enriching students' experience during 
reading comprehension activities. Journal of Educational Computing Research, 0(0): 1-36.

Osowski CP, Goranzon $\mathrm{H}$ and Fjellstrom C, 2013. Teachers' interaction with children in the school meal situation: the example of pedagogic meals in Sweden, Journal of Nutrition Education and Behavior, 45(5):420-427.

Pivec M, Dziabenko O and Schinnerl I, 2014. Aspects of game-based learning. Pers Ubiquit Comput, 17: 1647-1661.

Plass JL, Homer BD and Kinzer CK, 2015. Foundations of game-based learning, Educational Psychologist, 50(4): 258283.

Shaffer DW, Squire KR, Halverson $R$ and Gee JP, 2005. Video games and the future of learning. Phi Delta Kappan. 87(2): 104111.

Shah M and Foster A, 2015. Developing and assessing teachers' knowledge of gamebased learning. Journal of Technology and Teacher Education, 23(2): 241-267.
Strauss A and Corbin J, 2008. Basics of Qualitative Research: Techniques and Procedures for Developing Grounded Theory, third edition. Thousand Oaks, CA: Sage.

Thornton G and Cleveland J, 1990. Developing management talent through simulation. The American Psychologist, 45: 190199.

Viraj JS, 2016. Engaging students through board game: measuring its effectiveness on academic performance. International Journal of Environmental and Science Education, 10(6): 1-3.

William SE and Green JL, 2018. Childhood overweight and obesity: Affecting factors, education and intervention. Journal of Childhood Obesity, 3(29): 17.

Yien JM, Hung CM, Hwang GJ and Lin YC, 2011. A game-based learning approach to improving students' learning achievements in a nutrition course. The Turkish Online Journal of Educational Technology, 10(2): 1-11.

Table 1: Teacher A's development and implementation in game-based learning in nutrition topic

\begin{tabular}{|c|c|c|c|}
\hline $\begin{array}{l}\text { Pre-training } \\
\text { Interview }\end{array}$ & Construction of CoRe & $\begin{array}{c}\text { Classroom } \\
\text { Implementation }\end{array}$ & Training Impact \\
\hline \multicolumn{4}{|c|}{ Orientation to science teaching } \\
\hline Lecture-oriented. & Teacher-centered. & $\begin{array}{l}\text { Lecture-oriented, teacher- } \\
\text { centered. }\end{array}$ & $\begin{array}{l}\text { More student-oriented } \\
\text { with games. }\end{array}$ \\
\hline \multicolumn{4}{|c|}{ Knowledge about goals and objectives } \\
\hline General. & Focused and specific. & Focused and specific. & $\begin{array}{l}\text { Became more focused } \\
\text { and specific. }\end{array}$ \\
\hline \multicolumn{4}{|c|}{ Knowledge about students' understanding } \\
\hline $\begin{array}{l}\text { Appears to be well- } \\
\text { versed with students' } \\
\text { understanding of } \\
\text { previously learned } \\
\text { nutrition topics. }\end{array}$ & $\begin{array}{l}\text { Knowledgeable of } \\
\text { external factors } \\
\text { influencing students' } \\
\text { understanding on } \\
\text { nutrition topic. }\end{array}$ & $\begin{array}{l}\text { Facilitated the card games } \\
\text { well by pre-training the } \\
\text { students, but not the } \\
\text { board game. }\end{array}$ & $\begin{array}{l}\text { Found that game- } \\
\text { based learning was } \\
\text { engaging and was a } \\
\text { fun way to learn } \\
\text { nutrition topic. }\end{array}$ \\
\hline
\end{tabular}




\begin{tabular}{|l|l|l|l|l|}
\hline Knowledge about instructional strategies \\
\hline $\begin{array}{l}\text { Familiar with power } \\
\text { point presentation and } \\
\text { questioning technique. }\end{array}$ & $\begin{array}{l}\text { Familiar with power } \\
\text { point presentation and } \\
\text { listening game to } \\
\text { generate students' } \\
\text { participation. }\end{array}$ & $\begin{array}{l}\text { Relied too much on power } \\
\text { point presentation to } \\
\text { teach and introduce the } \\
\text { game rules. }\end{array}$ & $\begin{array}{l}\text { Wanted to learn more } \\
\text { card games to make } \\
\text { teaching and } \\
\text { learning process } \\
\text { interesting. }\end{array}$ \\
\hline $\begin{array}{l}\text { Knowledge about ways of assessing a specific topic } \\
\text { presentation } \\
\text { formative tests. }\end{array}$ & $\begin{array}{l}\text { Parental involvement } \\
\text { in nutrition education } \\
\text { is needed. }\end{array}$ & $\begin{array}{l}\text { Questions and nutrition } \\
\text { quiz. }\end{array}$ & $\begin{array}{l}\text { Became aware that } \\
\text { game is one way to } \\
\text { assess } \\
\text { students' } \\
\text { ond } \\
\text { nderstanding } \\
\text { nutrition topic. }\end{array}$ \\
\hline
\end{tabular}

Table 2: Teacher B's development and implementation in game-based learning in nutrition topic

\begin{tabular}{|c|c|c|c|}
\hline $\begin{array}{l}\text { Pre-training } \\
\text { Interview }\end{array}$ & Construction of CoRe & $\begin{array}{l}\text { Classroom } \\
\text { Implementation }\end{array}$ & Training Impact \\
\hline \multicolumn{4}{|c|}{ Orientation to science teaching } \\
\hline Student-oriented. & Student-centered. & $\begin{array}{l}\text { Student-oriented, } \\
\text { game-based. }\end{array}$ & $\begin{array}{l}\text { Gained confidence in } \\
\text { game-based learning. }\end{array}$ \\
\hline \multicolumn{4}{|c|}{ Knowledge about goals and objectives } \\
\hline General. & Focused and specific. & Focused and specific. & $\begin{array}{l}\text { Wanted to teach other } \\
\text { teachers how to write } \\
\text { CoRe. }\end{array}$ \\
\hline \multicolumn{4}{|c|}{ Knowledge about students' understanding } \\
\hline $\begin{array}{l}\text { Appears to be well- } \\
\text { versed with students' } \\
\text { prior knowledge and } \\
\text { vocabulary of nutrition } \\
\text { topics. }\end{array}$ & $\begin{array}{l}\text { Knowledgeable of } \\
\text { students' weakness in } \\
\text { vocabulary and prior } \\
\text { knowledge of } \\
\text { nutrition topic. }\end{array}$ & $\begin{array}{l}\text { Excellent. Met } \\
\text { students' needs by } \\
\text { pre-training student } \\
\text { leaders and grouping } \\
\text { them based on ability. }\end{array}$ & $\begin{array}{l}\text { Adapted game rules to } \\
\text { meet students' needs. } \\
\text { Wanted to teach } \\
\text { students to create } \\
\text { their own card games. }\end{array}$ \\
\hline \multicolumn{4}{|c|}{ Knowledge about instructional strategies } \\
\hline $\begin{array}{l}\text { Good with power point } \\
\text { presentation. }\end{array}$ & $\begin{array}{l}\text { Good with power point } \\
\text { presentation. }\end{array}$ & $\begin{array}{l}\text { Gave simple and clear } \\
\text { instructions in the } \\
\text { game play. }\end{array}$ & $\begin{array}{l}\text { Utilized the resources } \\
\text { (co-teachers and } \\
\text { student leaders) to } \\
\text { execute game-based } \\
\text { learning. }\end{array}$ \\
\hline \multicolumn{4}{|c|}{ Knowledge about ways of assessing a specific topic } \\
\hline Formative tests. & Formative tests. & $\begin{array}{l}\text { Nutrition quiz, game } \\
\text { debrief in each group } \\
\text { and random oral } \\
\text { presentation. }\end{array}$ & $\begin{array}{l}\text { Gain confidence in } \\
\text { using games to debrief } \\
\text { students. }\end{array}$ \\
\hline
\end{tabular}


Table 3: Teacher C's development and implementation in game-based learning in nutrition topic

\begin{tabular}{|c|c|c|c|}
\hline $\begin{array}{l}\text { Pre-training } \\
\text { Interview }\end{array}$ & Construction of CoRe & $\begin{array}{l}\text { Classroom } \\
\text { Implementation }\end{array}$ & Training Impact \\
\hline \multicolumn{4}{|c|}{ Orientation to science teaching } \\
\hline Teacher-centered. & Teacher-centered. & $\begin{array}{l}\text { Student-oriented, } \\
\text { game-based. }\end{array}$ & $\begin{array}{l}\text { Gained confidence in } \\
\text { game-based learning. }\end{array}$ \\
\hline \multicolumn{4}{|c|}{ Knowledge about goals and objectives } \\
\hline General. & Focused and specific. & Focused and specific. & $\begin{array}{l}\text { Gain confidence in } \\
\text { using CoRe. }\end{array}$ \\
\hline \multicolumn{4}{|c|}{ Knowledge about students' understanding } \\
\hline $\begin{array}{l}\text { Appears to be well- } \\
\text { versed with students' } \\
\text { ability and English } \\
\text { language proficiency. }\end{array}$ & $\begin{array}{lr}\text { Knowledgeable } & \text { of } \\
\text { students' } & \text { needs, } \\
\text { English } & \text { vocabulary } \\
\text { and } & \text { language } \\
\text { limitations. } & \end{array}$ & $\begin{array}{l}\text { Very good. Met } \\
\text { students' needs by } \\
\text { pre-training all leaders } \\
\text { and grouping them } \\
\text { based on ability. }\end{array}$ & $\begin{array}{l}\text { Adapted game rules to } \\
\text { meet students' needs. } \\
\text { Encouraged students } \\
\text { to make their own } \\
\text { game rules. }\end{array}$ \\
\hline \multicolumn{4}{|c|}{ Knowledge about instructional strategies } \\
\hline $\begin{array}{l}\text { Good with power point } \\
\text { presentation and } \\
\text { flashcards. }\end{array}$ & $\begin{array}{l}\text { Good with power point } \\
\text { presentation and } \\
\text { flashcards. }\end{array}$ & $\begin{array}{l}\text { Gave simple and clear } \\
\text { instructions in the } \\
\text { game play. }\end{array}$ & $\begin{array}{l}\text { Executed the card } \\
\text { games well. }\end{array}$ \\
\hline \multicolumn{4}{|c|}{ Knowledge about ways of assessing a specific topic } \\
\hline Formative tests. & Formative tests. & $\begin{array}{l}\text { Nutrition quiz, game } \\
\text { debrief in each group. } \\
\text { Oral questions and } \\
\text { answers. }\end{array}$ & $\begin{array}{l}\text { Gain confidence in } \\
\text { using games to debrief } \\
\text { students. }\end{array}$ \\
\hline
\end{tabular}


Table 4: Cross-case study of the results of in-service primary science teachers' development and implementation in game-based learning in nutrition topic after attending the training workshop

\begin{tabular}{|c|c|c|c|c|c|}
\hline No & Aspects of Assessment & Teacher A & Teacher B & Teacher C & Mean \\
\hline 1 & $\begin{array}{l}\text { Explain learning objectives related to nutrition } \\
\text { topic }\end{array}$ & 3 & 5 & 4 & 4 \\
\hline 2 & $\begin{array}{l}\text { Using proper strategies and approaches to teach } \\
\text { nutrition topic }\end{array}$ & 3 & 5 & 4 & 4 \\
\hline 3 & Demonstrating mastery of card game & 4 & 4 & $\mathrm{n} / \mathrm{a}$ & 4 \\
\hline 4 & Demonstrating mastery of board game & 2 & 4 & 5 & 3.7 \\
\hline 5 & $\begin{array}{l}\text { Identifying students' particular ways of thinking } \\
\text { about nutrition concepts }\end{array}$ & 2 & 5 & 4 & 3.7 \\
\hline 6 & $\begin{array}{l}\text { Identifying certain students who have } \\
\text { misunderstandings about nutrition concepts, } \\
\text { then giving an explanation }\end{array}$ & 2 & 4 & 4 & 3.3 \\
\hline 7 & Identifying tasks students feel difficult to do & 2 & 5 & 4 & 3.7 \\
\hline $\begin{array}{l}8 \\
9\end{array}$ & $\begin{array}{l}\text { Demonstrating ability to modify game rules } \\
\text { Linking nutrition concepts to knowledge } \\
\text { possessed by students }\end{array}$ & $\begin{array}{l}1 \\
3\end{array}$ & $\begin{array}{l}4 \\
5\end{array}$ & $\begin{array}{l}5 \\
4\end{array}$ & $\begin{array}{c}3.3 \\
4\end{array}$ \\
\hline 10 & Motivating students to interact in games & 2 & 5 & 4 & 3.7 \\
\hline 11 & Linking nutrition concepts with everyday life & 2 & 5 & 4 & 3.7 \\
\hline 12 & Performing skills for teaching card game & 4 & 4 & $\mathrm{n} / \mathrm{a}$ & $4^{*}$ \\
\hline 13 & Performing skills for teaching board game & 1 & 4 & 5 & 3.3 \\
\hline 14 & $\begin{array}{l}\text { Implementing card games well, so students are } \\
\text { interested and focused on learning through play }\end{array}$ & 4 & 4 & 4 & 4 \\
\hline 15 & $\begin{array}{l}\text { Implementing board game well, so students are } \\
\text { interested and focused on learning through play }\end{array}$ & 1 & 4 & 5 & 3.3 \\
\hline 16 & Using good and correct spoken language & 3 & 5 & 4 & 4 \\
\hline 17 & Monitoring learning progress during GBL & 2 & 5 & 4 & 3.7 \\
\hline 18 & Reflecting by involving students & 2 & 5 & 4 & 3.7 \\
\hline 19 & $\begin{array}{l}\text { Conducting evaluation of students' nutrition } \\
\text { knowledge }\end{array}$ & 2 & 5 & 4 & 3.7 \\
\hline 20 & $\begin{array}{l}\text { Follow up by providing direction, or activities, or } \\
\text { assignments as part of remedies/enrichments }\end{array}$ & $\mathrm{n} / \mathrm{a}$ & $\mathrm{n} / \mathrm{a}$ & $\mathrm{n} / \mathrm{a}$ & $\mathrm{n} / \mathrm{a}$ \\
\hline
\end{tabular}

Notes: 1) Very low, 2) Low, 3) Moderate, 4) High, 5) Very high 